\title{
INCOMPATIBLE WORLDS? PROTESTANTISM AND COSTUMBRE IN THE ZAPOTEC VILLAGES OF NORTHERN OAXACA ${ }^{1}$
}

\section{Toomas Gross}

\begin{abstract}
In recent decades, Protestant population has grown rapidly in most Latin American countries, including Mexico. The growth has been particularly fast in rural and indigenous areas, where Protestantism is often claimed to trigger profound socio-cultural changes. This article discusses the impact of Protestant growth on customs, collective practices and local identities using the example of indigenous Zapotec communities of the Sierra Juárez in northern Oaxaca. Drawing on the author's intermittent fieldwork in the region since 1998, most recently in 2012, the article first scrutinises some of the recurring local perceptions of Protestant growth in the Sierra Juárez and their impact on communal life. Particular attention will be paid to converts' break with various customary practices pertaining to what locally is referred to as usos y costumbres. The article will then critically revise the claims about the culturally destructive influence of Protestantism, suggesting that the socio-cultural changes in contemporary indigenous communities of Oaxaca may actually be caused by more general modernising and globalising forces, and that the transformative role of Protestantism is often exaggerated.
\end{abstract}

Key words: Protestantism, indigenous customs, culture, identity, Oaxaca, Zapotecs

\section{INTRODUCTION}

Since the 1960s, Protestant churches - various Pentecostal and neo-Pentecostal churches in particular - have grown rapidly in Latin America. The alleged corollaries of this growth - converts' emphasis on success and prosperity, more individualist worldview, and more emotional relationship with one's faith - have often been considered by scholars as vehicles of much broader and deeper social and cultural changes than the mere fragmentation of the 'religious field' or the makeover of individual converts' lives. Even though it is the individuals who convert, en masse conversions are claimed to transform entire communities and societies. This may entail novel forms of social organisation, changes in collective practices, new modes of thinking, and new values. In rural indig- 
enous communities, Protestants propagate breaking the links with the past that are maintained through customs and traditions. To emphasise the deeply transformative effect of Protestant growth on contemporary Latin America, Patterson (2005: 45) calls this process a 'religious revolution'. Although such a claim is probably an overstatement, it is not entirely off the mark in certain contexts. Historically, Catholicism has become tightly entangled with cultural as well as social and political identities in Latin America, both on national and on local levels. Although Catholicism has not penetrated all communities and indigenous life-worlds in Latin America, it is strongly present in most of them, albeit in multiple syncretic forms. Given such a strong link between Catholicism and cultural identity, religious change has to have a significant socio-cultural impact.

The aim of this article is to explore the latter claim in the ethnographic example of indigenous Zapotec communities of the Sierra Juárez of Oaxaca in Southern Mexico. The discussion is based on my intermittent fieldwork in the region since $1998 .^{2}$ I endeavour to critically review the putative relationship between the growth of Protestant population and the recent socio-cultural changes in the indigenous villages. As I will suggest, Protestantism does have an impact on local cultural practices and the 'collective consciousness' in the Zapotec villages of the Sierra Juárez, but its transformative role should not be exaggerated. Various Protestant groups adapt to local customs and cultural practices relatively easily, rather than reject them. Moreover, the socio-cultural changes that are often claimed to be the result of Protestant growth can have other primary causes.

\section{THE DYNAMICS OF PROTESTANTISM IN MEXICO}

In most Latin American countries the Catholic Church has for centuries enjoyed a privileged position, often granted to it by law. Although Protestantism ${ }^{3}$ in Latin America dates back at least to the beginning of the 19th century (Mondragón 2005: 47-49), until the mid-20th century Protestant groups in most countries were few, the percentage of Protestants in the population insignificant, and the rise in their numbers very slow. Roughly in the 1960s, however, membership growth in Protestant churches exploded, leading David Stoll (1990) to famously ask in the title of his well-known book: "Is Latin America turning Protestant?" The rise of Protestantism has been particularly marked in Brazil, Chile and Central America, where Protestants now constitute more than twenty percent of the total population. 
Protestant growth in Mexico has been considerably more sluggish, which is partly explainable by various historical factors. The hegemonic position of the Catholic Church in the Mexican society was secured during the early years of independence. The fourth article of the first federal constitution, Acta Constitutiva de la Federación (1824), declared:

The religion of the Mexican nation is and will always be Catholic, Apostolic, Roman. The nation protects it with clever and just laws and prohibits the exercise of any other. (cf. Aguirre 1992: 192)

Considering such a favoured position of the Catholic Church in the early 19th century Mexican society and the colonial legacy, it is not surprising that Catholicism has gradually evolved to constitute an integral part of the Mexican national culture. ${ }^{4}$ One might even argue that Catholicism co-defines the Mexican national identity and constitutes a source of dominant national symbols. Most notable among these is the Virgin of Guadalupe, the 'master symbol' of Mexico according to Wolf (1958: 34). Some earlier scholars went as far as to claim that Catholicism 'suits' the 'Mexican mentality' and especially the country's indigenous population better than Protestantism. For example, Manuel Gamio, the 'founding father' of Mexican anthropology, suggested in his Forjando patria (Forging a Nation), first published in 1916:

The transition from indigenous paganism to Catholicism [in Mexico] found no obstacles because from the indigenous point of view both faiths were analogous, which favoured their religious fusion. Paganism and Protestantism, however, were different and counter-symbolic in their essence and form. [...] It is thus logical that the Mexican Indians voluntarily accept the Catholic creed, assimilating it in their own manner, and reject Protestantism because it appears to them abstract, exotic, iconoclastic, incomprehensible. (Gamio 1982: 87-88)

Esquivel, a Catholic and fervently anti-Protestant lawyer, extrapolated a similar argument to the whole of Latin America. "The Hispano-American soul is not adaptable to Protestantism," he (1946: 66) confidently claimed.

In the first half of the 20th century, the Catholic Church in Mexico also adopted a strongly 'nationalist' discourse to confront the 'Protestant danger' (e.g. Crivelli 1929). Protestants were accused of serving the interests of the United States, because they challenged Catholicism, which was considered the main source of cultural resistance against the North American influence. ${ }^{5}$ A radical journal of that era entitled Amauta stated in 1927: "The Protestant creed is to us an anti-nationalist cult, an instrument of conquest, manipulated by a foreign race." (cf. Mondragón 1994: 331) 
Closely linked to such 'nationalist' rhetoric has been the so-called 'culturalist discourse' against Protestantism, rooted in the above-mentioned perception that Catholicism in Mexico is not a religion like any other but a 'worldview' that sustains the national identity and provides the Mexican nation with its most important collective symbols. Mondragón (1994: 331) eloquently calls such a mode of thinking 'Guadalupanism'. Rejecting the saints, Protestants also reject the Virgin of Guadalupe and consequently have a destructive impact on the national and cultural identity, as the critics argue (De la Torre 1995: 9).

Condemning Protestantism publicly on nationalist and culturalist grounds was, of course, more common in the first half of the twentieth century. Yet such reasoning has been slow to vanish especially in Southern Mexico (Blancarte 1992: 417), and was still a relatively common constituent of the rhetoric of the Oaxacan Catholic clergy in the 1980s and 1990s. Also, as I will demonstrate below, the 'culturalist' and 'nationalist' argumentation against the spread of Protestantism is still existent in the contemporary indigenous communities of the Sierra Juárez.

Despite the strong resistance to Protestantism by the Catholic Church, the general dynamics of Protestant growth in Mexico are reminiscent of the trends in the rest of Latin America. It means, above all, that rapid and almost exponential growth has replaced the slow linear increase of Protestant population in recent decades. The Mexican census data demonstrate this vividly (Fig. 1). ${ }^{6}$ Two significant trends within the process of Protestant spread in Mexico, reminiscent of those in the rest of Latin America, stand out. Firstly, Protestant growth has in most contexts become synonymous with what might be called 'Pentecostalisation'. In other words, Pentecostal and especially Neo-Pentecostal churches are now growing much faster than the so-called 'historical' Protestant denominations (e.g. Lutheran, Methodist, Presbyterian, Baptist, and Anglican churches). The trend is common to most of Latin America. As Hernández (2007: 73) claims, possibly as many as 70 to 75 percent of all non-Catholics in contemporary Latin America are Pentecostals. The other noteworthy trend in Mexico is the shift in the 'demographic weight' of Protestant growth. Until the middle of the 20th century, most Protestant converts lived in urban centres and in mestizo communities, and belonged to the middle class. For the past few decades, however, Protestant growth has been mainly powered by conversions in rural areas, in indigenous communities, and among lower classes. ${ }^{7}$

Since the path-breaking studies by Lalive d'Epinay (1968) and Willems (1964, 1967), and especially from the early 1990s onwards, Protestant growth has been claimed to cause profound socio-cultural changes in Latin America. Stoll (1990) and Martin (1990), for example, consider Protestantism in Latin America a 'vehicle of modernity'. Garrard-Burnett (1993) calls the rise of Protestantism 


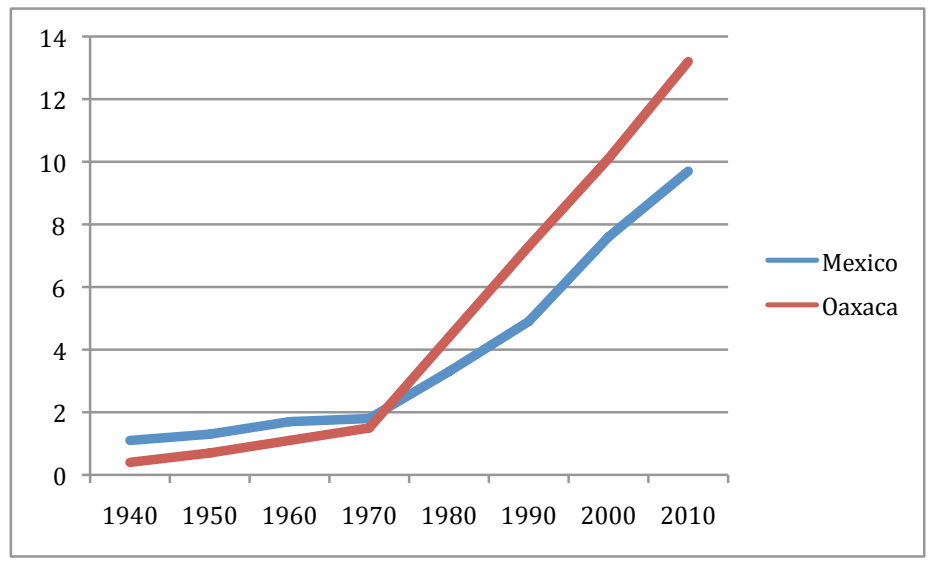

Figure 1. Protestant growth in Mexico and in Oaxaca. ${ }^{8}$

on the continent 'Latin America's Reformation'. Patterson (2005: 155), in turn, claims that Protestantism in Latin America alters the societies' value-systems and increases political mobilisation. Mondragón (2005), focusing on Mexico, endows the Protestant social thought with various new values inculcating the Mexican society. Protestantism in rural Mexico has been regarded as a 'new social movement' (Montes 1997; Gutiérrez Zúñiga 2000). The following discussion, rooted in my fieldwork experience, assesses the alleged impact of Protestantism on the Zapotec villages in the Sierra Juárez of Oaxaca and consequently takes a more moderate stance than the above-mentioned approaches.

\section{ETHNOGRAPHIC CONTEXT: THE SIERRA JUÁREZ OF OAXACA}

As argued above, Protestant growth in contemporary Latin America as well as in Mexico has been the fastest among the poor and indigenous populations. The State of Oaxaca, the broader context of this study, is the most indigenous and one of the poorest among 31 Mexican states, and hence an appropriate ethnographic setting for studying the implications of Protestantism. Although the percentage of Protestants in Oaxaca is not as high as in various neighbouring states - Chiapas, Tabasco and Veracruz especially - the increase of Oaxacan Protestant population during the past forty years has nevertheless been remarkable (Fig. 1). ${ }^{9}$

My research in Oaxaca focuses on the Sierra Norte, the mountainous northern part of the state, and more specifically on one of its regions called the Sierra Juárez. Although the economic and demographic conditions in the 
contemporary villages of the Sierra Juárez vary, significant similarities allow the area to be regarded as a single socio-cultural entity. The majority of the population of the Sierra Juárez are indigenous Zapotecs ${ }^{10}$, although Chinantec villages are also numerous in the north-western part of the region. The size of most communities ranges between 500 and 2,000 inhabitants. All villages are socio-politically organised on the basis of what locally is referred to as usos $y$ costumbres $^{11}$ - a diffuse body of customs, norms, and practices that defines the administration of villages and regulates the relations between villagers. Usos $y$ costumbres embrace religious practices rooted in (folk) Catholicism. The most significant among these is the fiesta organised yearly in honour of the village patron saint (fiesta patronal). But usos y costumbres also entail local modes of social and political organisation, most notably the system of cargos, which in Mexico and historically in all of Mesoamerica stands for a hierarchical system of communal responsibilities. Characteristic of the socio-political organisation of indigenous villages are also specific forms of political succession, modes of decision-making, and legal procedures. Usos y costumbres also embrace native forms of collective labour, usually called tequio and guelaguetza. The former stands for obligatory and non-remunerated labour for the general benefit of the village. Guelaguetza, in the context of the Sierra Juárez, refers to the voluntary

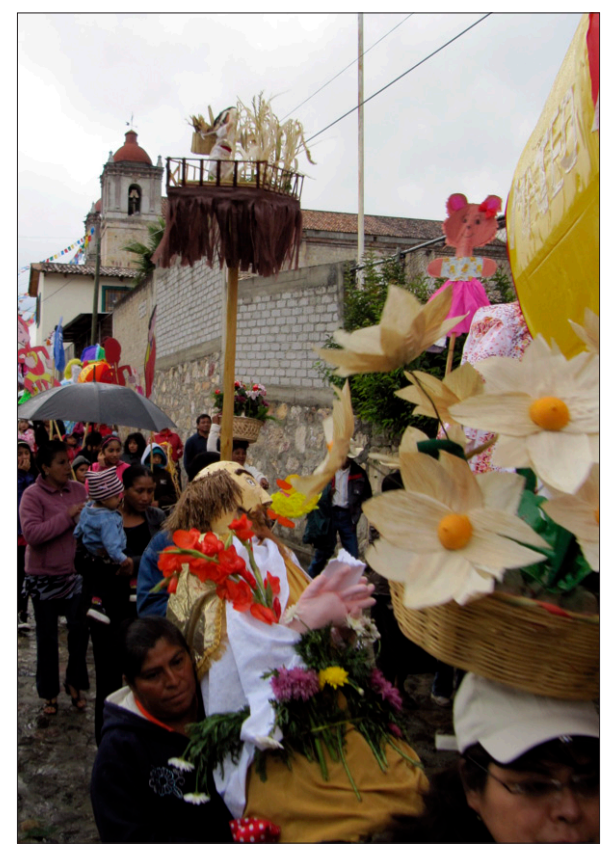

Figure 2. A procession during the fiesta patronal in Capulálpam. Photo by Toomas Gross 2009. 
economic collaboration between individual households on ritual occasions such as weddings, funerals, and fiestas.

All these practices are considered 'autochthonous' and they constitute an important source of communal pride and a strong basis for collective identity in the indigenous villages. The legitimacy of the usos y costumbres stems from the common perception that they are native practices, norms, and values 'inherited from the past generations', but also from the fact that most of these practices are believed to reinforce communal solidarity, unity, and stability. "Here costumbre is a law," I was often told by villagers in the Sierra Juárez. As an informant from the town of Ixtlán claimed, "Usos y costumbres are an important heritage that allows us to live in peace and secure respect between members [of the community]." Another informant from the village of Xiacui defined usos y costumbres as the 'brotherhood between people'. Villagers in the Sierra Juárez consider the preservation and protection of native cultural, economic, and administrative practices not simply as a moral responsibility but also as something that is vital for the survival of indigenous communities in the globalising world. The discussion of usos y costumbres, both in local contexts, scholarly texts (e.g. Aguirre 1991; González 1994; Gómez 1997; Durand 1998),

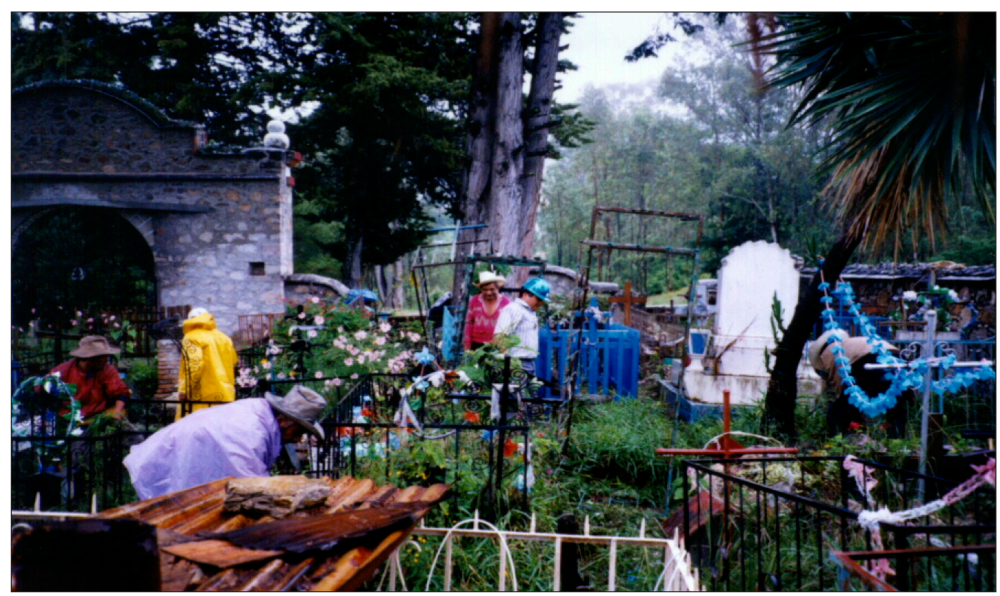

Figure 3. Tequio at the cemetery of Capulálpam during the Day of the Dead. Photo by Toomas Gross 2008.

and since the early 1990 s also by the state ${ }^{12}$, is often linked to the topics of human, communal, and indigenous rights.

Inhabitants of most villages of the Sierra Juárez strongly identify themselves with the community as a place and as a corporate social entity. Berg (cf. Hi- 
rabayashi 1993: 11) calls this phenomenon pueblismo. A number of anthropological studies from the 1970s onwards have emphasised the exceptionally strong feeling of communal identity in the Sierra Juárez. Kearney (1971: 331) emphasises the pursuit of harmony and peace in the community called Ixtepeji, which manifests in highly valued unity and internal solidarity. De la Fuente (1977: 210), studying the village of Yalálag, claims that "a Yalalteco [...] expresses great affection and attachment to his village, the place that for him is unique although it is similar to [other communities] that he knows". Nader (1990: 3) in her well-known account of a Zapotec dispute settlement similarly suggests that the ideologies of harmony and solidarity are deeply embedded in the social organisation of contemporary Zapotec villages. Alatorre (1998: 79) has argued that the Zapotec villages of the Sierra Juárez are moral communities with "very intense interaction and very high level of acceptance of the same values by its members".

My own observations and interviews in the Sierra Juárez also confirm that according to the villagers' idealised perception, their native communities are socially and spatially bounded entities, exclusive in terms of membership, autonomous and characterised by high levels of intimacy, unity, homogeneity, and an uncompromising emphasis on solidarity. As an informant from Tabaa suggested, "Community [la comunidad] represents a group of people who are intimately related." A young man from Yojovi had a similar perception of his native village: "[A community] is a group of individuals who are very united (muy unidos)," he argued. "Community means living in a fraternal union with the ones who surround us, serving and helping each other in peace," another informant from Las Palmas claimed. Although these perceptions obviously represent the desired state of affairs rather than the actual villages, such idealisation affects the social reality in intricate ways. Most importantly, it determines the nature of the villagers' criticism of individuals, groups, and processes that are considered a threat to this idealised model. Protestants, as I will demonstrate below, are often regarded as one of such groups.

Like the rest of Oaxaca, most of the Zapotec communities of the Sierra Juárez have experienced a considerable increase of Protestant population during the past few decades. The spread of Protestantism fragments the communities as idealised hypothetical wholes into different and often antithetical religious lifeworlds. The discussions of Protestant growth and its impact in rural Oaxaca are by now multiple, ranging from the assessment of its influence on gender relations (Sault 2001) and economic development (Marroquín 1995b; Montes 1995; Sánchez 1995) to more general scrutiny of the links between Protestantism and modernisation (Gross 2003), or 'indigenous culture' (Gallaher 2007). My focus in the discussion that follows is more moderate - I will limit myself 


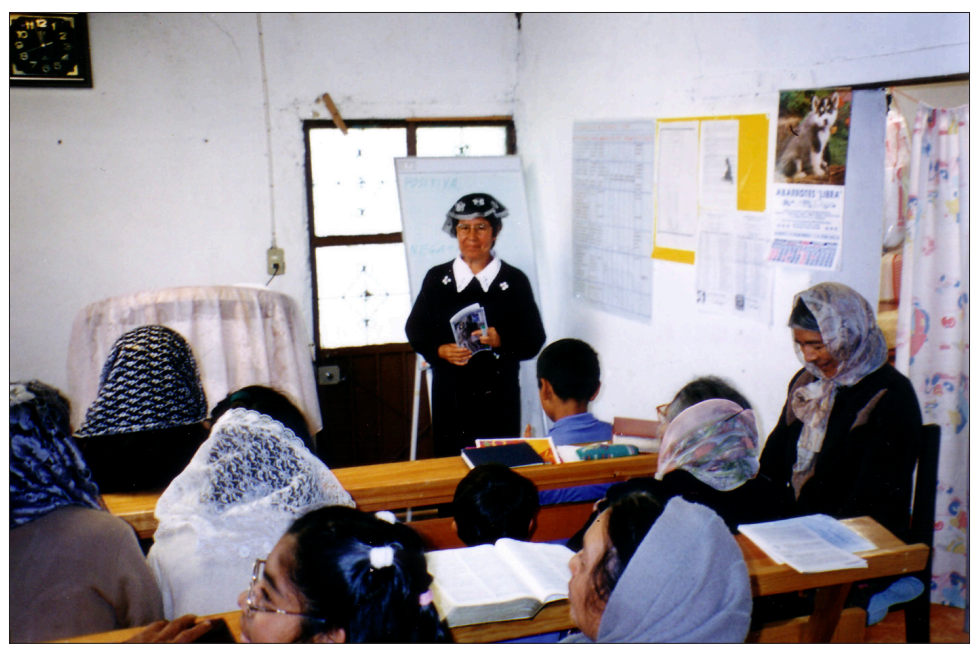

Figure 4. A weekly meeting at the Iglesia de Dios in Capulálpam. Photo by Toomas Gross 2000.

to critically scrutinising the local claims concerning the Protestants' impact on certain aspects of usos y costumbres.

\section{INCOMPATIBLE WORLDS?}

In most villages of the Sierra Juárez, the Protestant population still constitutes a religious minority, despite its remarkable growth in recent decades. Nevertheless, many villagers consider the impact of Protestantism on communal life and customs to be substantial. In the local discourse this impact is often perceived in negative terms, although such claims are occasionally also present in scholarly analyses. Barabas (2006), for example, claims that Protestantism and transnational migration constitute the most serious challenges to the socio-cultural organisation of contemporary indigenous communities of Oaxaca. The spread of Protestantism contributes to the situation where traditional indigenous cosmologies are "discursively cancelled, prohibited, and demonised" (Barabas 2006: 127).

Central to the critical arguments against Protestantism, both locally and in scholarly analyses, is that the 'ideology of discontinuity' and 'born again' worldview of Protestant converts advocates a break with the past. ${ }^{13}$ Customs and traditions - various elements of the usos y costumbres in the case of the Sierra 
Juárez - are manifestations of the past and hence to be rejected. Protestants tend to regard customs (costumbres), especially those related to Catholicism, as a source of idolatry and paganism. My Protestant informants often thought of costumbre as the main obstacle to finding the 'truth' and the God. But customary norms and practices may also be criticised from the human rights perspective, due to their obligatory and collective essence.

The worldview and the values that Protestantism encourages are considered to be incongruent with the collective communal ethos in indigenous villages. For the majority of its native inhabitants, community, both as a social and as a geographical entity, its customary norms and religious (Catholic) practices constitute the prime foundation for collective identity and group solidarity. Protestant converts, however, switch from collective to more individual lifestyles and reject various communal practices, which have traditionally served as socially unifying mechanisms of an indigenous village. When converting to Protestantism, the emotional link between various communal symbols and the individual is broken. Protestants no longer need patron saints as mediators between them and the God. Their relationship with the transcendental is established through the individual study of the Bible and not through the collective veneration of a patron saint. "Our aim is to please God and not people," a Jehovah's Witness told me, emphasising his immediate relationship with God. Converts no longer regard various collective projects of the (Catholic) community as their own. Such communal responsibilities are secondary to their responsibilities to God and the converts' solidarity with other villagers is often weaker than the solidarity with their religious 'brothers' and 'sisters' of any congregation of their new church in the world.

The (negative) impact of the increase of Protestant population is considered to be most immediate and discernible on practices related to Catholicism, especially the fiestas organised in honour of village saints. The growth of Protestant population influences the organisation and the nature of fiestas in two ways - it leads to the decline in material contributions needed to finance the event, as well as to the decreased number of participants. In the past, fiestas were financed by individual sponsors (mayordomos), who were nominated by other villagers from among the most affluent men in the village. In recent decades, however, the collective financing of the fiestas has replaced the mayordomía system in most communities. This means collecting the 'festival quota' (cuota) from individual households. Ideally, paying the cuota is obligatory to all households but Protestants often refuse to do it. This has led to disputes and confrontations between Protestants and village authorities in numerous cases. Balthazar, a former Municipal President of one of the villages, recounted his experience with the Jehovah's Witnesses who had refused to contribute to financing the fiesta: 
Occasionally, some [Protestants] - those who were of another religion and did not like saints - did not want to pay the cuota. I, as the representative of the authority, had to talk to them. I said: 'I have seen you during the dances, playing basketball, during the fairs. Why don't you want to cooperate? The money that you are going to give is not for the saint, it is for the procession and other things, for the fiesta of the community.' You have to explain to them so that they will not misunderstand - not everything in the fiesta is religion.

In some villages of the Sierra Juárez Protestants have given in to the authorities' pressure, whereas in other villages they are exempt of paying. Capulálpam is an example of a compromise between these two extremes: Protestants are not obliged to pay the cuota for the fiesta but they are supposed to pay an equivalent sum of money for financing alternative communal projects. Jehovah's Witnesses, for instance, have for various years allocated their money for purchasing light bulbs for street lighting.

Protestants refuse to participate in the Catholic fiestas not only because they consider worshipping saints idolatrous but also because such events are regarded as socially and economically harmful. Fiestas are associated with the consumption of alcohol and the 'burning of money' (la quema del dinero), as some Protestants call it. Owing to the fact that many villagers now reject the fiesta due to their new religious convictions, the meaning of the fiesta has changed for everyone. The earlier 'communal event' has now transformed into a 'Catholic' one, associated not with the whole community but with only one, albeit usually the major religious group in the village.

The impact of the increase of Protestant population on the religiously more 'neutral' communal practices, such as the system of civil cargos and tequios, is generally considered to be weaker. Although claims that all Protestants reject all aspects of usos y costumbres are not uncommon among the most severe critics, the truth is rather that some Protestant groups refuse to participate in some of the customary practices, if these go against their religious convictions. The Seventh Day Adventists would refuse to participate in the tequios that are held on Saturdays. The Jehovah's Witnesses would not accept highly ranked cargos, since their religion forbids them to get involved in politics. Victor, a Jehovah's Witness in his mid-twenties, described his attitude towards different cargos:

I never served as a llavero $^{14}$, because it is a religious cargo and entails responsibilities in the Catholic Church. It might well be that someday the village will decide that since I have not served as a llavero, I have to do it. They say that everyone has to do all the cargos. But I won't do it. One has to follow the orders of village authorities, but as Jehovah's Wit- 
nesses we cannot always do so - when the orders go against the Bible. They force us sometimes, but there are also human rights. We, Jehovah's Witnesses only accept cargos up to the level of regidor ${ }^{15}$. Anything further up from there is already politics.

All this is considered by critics to have culturally destructive consequences. Mario, a middle-aged Catholic man from Ixtlán, lamented over the devastating impact, in his opinion, of Protestantism on local customs and the difficulties that the village authorities had to face nowadays, when trying to force Protestants to obey the customary norms:

[The Protestants] do not participate in tequios, but you cannot force them. If we incarcerate them for not participating or not cooperating for the fiesta, the human rights activists come and criticise us. Why do we punish the Protestants, if Mexico is a free country, they ask. The customs and traditions are vanishing as a result of all this.

An example of such a community in the Sierra Juárez, often singled out by my informants as a prototype of the culturally destructive consequences of Protestantism, is Madero, a tiny Zapotec village of approximately 300 inhabitants. Protestants belonging to four different churches clearly outnumber the Catholic population in that village. The social life in Madero is centred solely in religious congregations, and most ritual practices that used to unite the whole village, including the fiesta of the patron saint, have disappeared. Catholics in other villages often referred to Madero as an alarming example of the adverse impact of religious fragmentation on local customs and communal solidarity. The situation in Madero was often used to justify one's intolerance towards religious pluralism. As an informant from a neighbouring village argued, allowing Protestants to the villages would eventually lead to what had happened in Madero, where, according to him, "customs have disappeared and the community is dead."

Historically, Protestant growth has led to numerous religious conflicts in all of Oaxaca, especially in the 1990s. It is important to note, however, that actions taken against Protestants in the villages have generally not been caused and motivated by religious intolerance per se. What has usually mobilised the critics and village authorities is the Protestants' reluctance to participate in certain collective activities. Such reluctance goes against the idealised perception outlined above that many (Catholic) villagers have of an indigenous community and social solidarity. Various examples of religious conflicts in the Sierra Juárez in the 1980s and 1990s illustrate this eloquently. In San Pedro Cajonos, for example, the authorities closed the local Adventist church, deprived its members of electricity, and prohibited all village shops to sell goods to Adventists because 


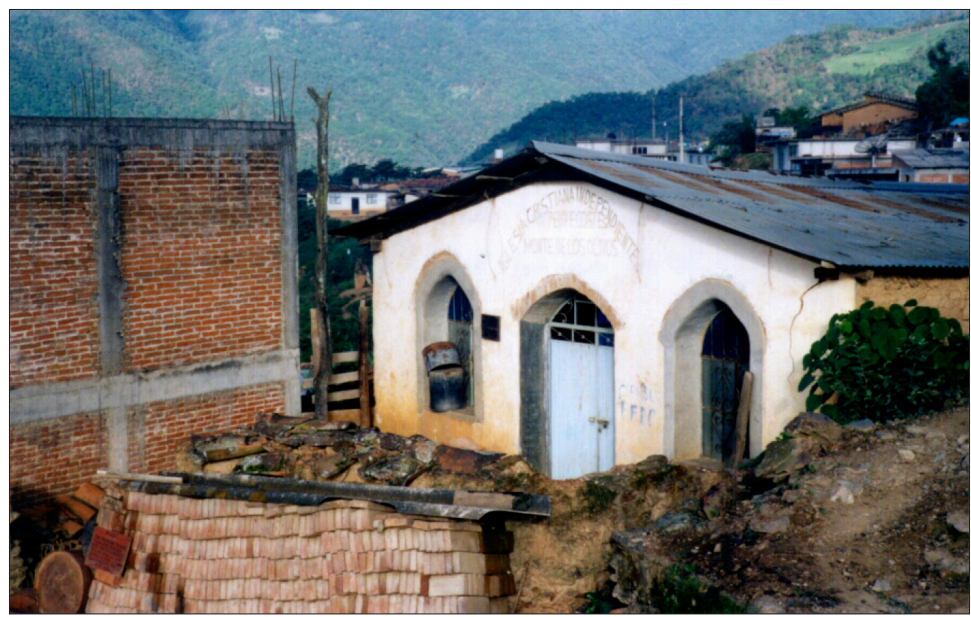

Figure 5. A Pentecostal church forcefully closed by village authorities in Solaga. Photo by Toomas Gross 2000.

the latter had allegedly refused to participate in various communal practices. ${ }^{16}$ In Teotlaxco and Tabaa, Protestants were attacked on multiple occasions for not taking part in tequios. In Capulálpam, according to various testimonies, the Jehovah's Witnesses were forced to participate in communal activities under the threat of being expelled. These are but some examples.

Although Chiapas is the state that has experienced the worst cases of religious intolerance in recent Mexican history, the actual number of religious conflicts in the past few decades has been the highest in Oaxaca. Mutual criticism, threats, fines, restrictions on preaching and proselytising, detentions and expulsions, destruction of Protestants' property, and the demolition of Protestant churches were recurring phenomena in many Oaxacan villages, also in the Sierra Juárez, in the 1980s and 1990s. This era was the height of religious intolerance in rural southern Mexico. Importantly, nearly two thirds of the cases of intolerance during that time occurred in relatively small villages of 500-2,500 inhabitants (Montes 1995: 33). This is not necessarily surprising, considering that the feeling of intimacy in such small communities is obviously stronger than in bigger ones. Consequently, the fears of the potentially disruptive effect of religious 'otherness' on communal ethos and solidarity are also stronger. It should also be emphasised that although occasionally some critics lump all non-Catholic churches together, their adverse impact on local customs is more usually regarded as being denomination-specific. Jehovah's Witnesses, Adventists, and Mormons are usually considered to be the most inflexibly opposed to local 
customs, while Pentecostal and Neo-Pentecostal churches and especially the so-called 'historical Protestants' (e.g. Lutherans, Presbyterians, Methodists) are perceived in a less negative light. The difference in the attitudes towards Protestant denominations correlates with the frequency of their involvement in religious conflicts (Montes 1997: 58).

The origin of the members of Protestant churches also affects the Catholic majority's attitudes towards them. In Capulálpam, for example, Catholics' feelings about the Seventh Day Adventists were generally less negative than their attitude towards the Jehovah's Witnesses. The former are mainly natives of Capulálpam while the latter are predominantly migrants from other villages. As a Catholic woman claimed: "Adventists are from here, [...] one has to respect them because of that." The attitude towards the Jehovah's Witnesses, however, was often either condescending or worse. The fact that the Jehovah's Witnesses do not salute the national flag, reject not only Catholic but also many civic and patriotic rituals, and refuse to be nominated for higher cargos enabled the village authorities and the Catholic majority to criticise them on nationalist grounds.

But the 'nationalist card' is often also played against other Protestant denominations, especially when trying to present Protestantism as a 'foreign influence'. Many of my Catholic informants justified their intolerance towards Protestants with the claims that Protestantism is 'a conspiracy of other nations' (complot de otras naciones). In Capulálpam, almost a quarter of the Catholic respondents (86 in total) to my questionnaire on various issues related to religion and the village believed that Protestant growth in the Sierra Juárez was mainly explainable by the US influence. The converts into 'foreign religions' were accused of deceiving Mexico and making 'pacts with the gringos'. The religious conflict in the village of San Juan Yaeé, pending throughout the 1990s, illustrates well how the nationalist as well as culturalist arguments against Protestants have been employed. The conflict in Yaeé was probably the most heated and long-lasting confrontation among many comparable cases of religious intolerance during that era in the Sierra Juárez. The conflict began in 1991, when various members of the local Pentecostal church were detained by the village authorities, allegedly for practicing a non-Catholic religion without the authorities' consent. Although an agreement was soon signed between the Pentecostals and the authorities, regulating and restricting Protestants' religious practices in the village, detentions, threats and fines continued for years, culminating in 1996 in the expulsion of 52 Pentecostals from the village and the destruction of their church building. The municipal president justified the authorities' forceful measures in the following manner: 
The Protestants come here with the ideology of the gringos and only constitute a hindrance to social peace. There is a conflict because we organise ourselves by usos y costumbres and they impose the law of the gringos. ${ }^{17}$

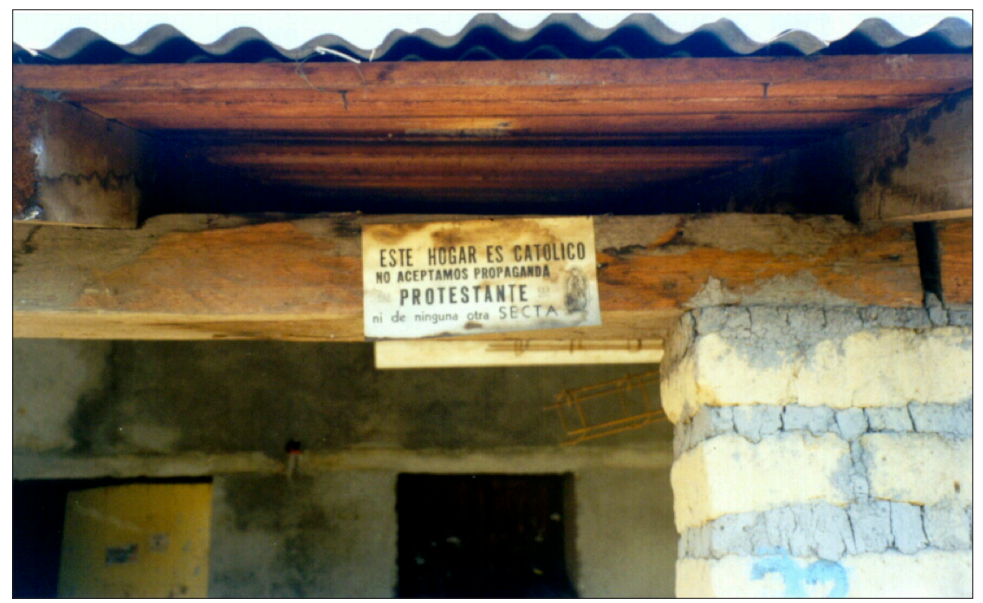

Figure 6. An anti-Protestant sign on the entrance to a house in Ixtlán. Photo by Toomas Gross 2008.

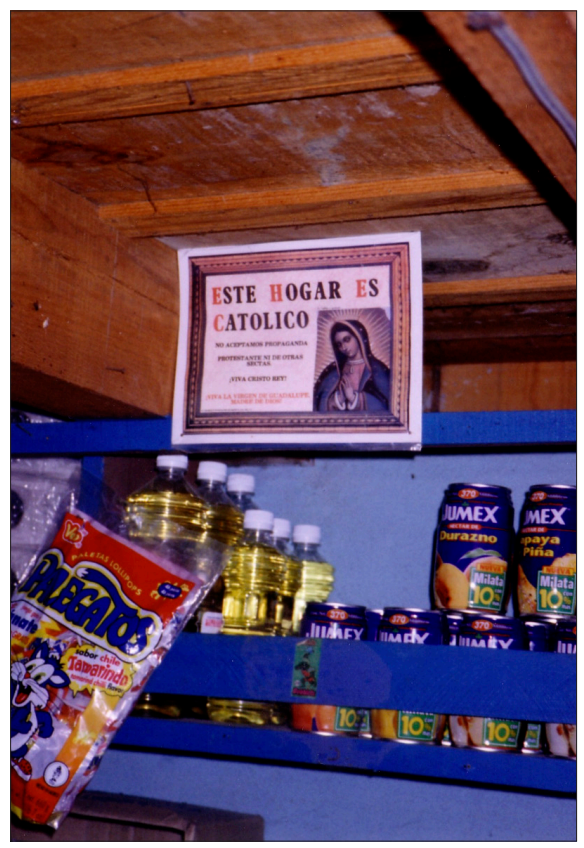

Figure 7. An anti-Protestant sign in a shop in Capulálpam. Photo by Toomas Gross 2008. 
Not only are Protestants accused of disseminating foreign ideas and ideology, but it is often also believed that their activities are financed with foreign money. As Pablo, an ardent Catholic, suggested:

I think that the Protestants are paid for converting. This money comes from the United States. They always travel around proselytising here and there with a Bible in their hands, but they do not work like us - where else do they get money for food?

Such 'nationalist' and 'culturalist' critique of Protestant growth is occasionally backed up by economic reasoning. The spread of Protestantism, by fragmenting the communities ideologically, undermining communal solidarity, and affecting local customs, is feared to eventually enable foreign countries, especially the United States, to appropriate and control Mexico's natural resources. Judging by the articles published in the Oaxacan and national media, this was a common argument in Mexico in the 1970s among many - also anthropologists - who lobbied against the activities of the Summer Institute of Linguistics (SIL), a controversial faith mission. But similar fears were expressed also by some of my informants in the Sierra Juárez. As the Catholic priest of Ixtlán claimed:

Protestantism is an incentive by gringos to divide our nation and our villages. They want us not to be united and not to guard our natural resources, and their intention is to divide and conquer. For example, various American missionaries of the Summer Institute of Linguistics came to Yagallo to study local languages, customs and culture - everything that unites the people. But their real aim was to do away with the cultural roots of the village.

\section{THE CULTURAL DESCTRUCTIVISM ARGUMENT REVISED}

Although it is undisputable that joining the Protestant churches transforms the converts' worldview and leads to their rejection of certain local customs and practices, especially those related to the Catholic Church and the Catholic faith in general, the argumentation and claims presented above need to be critically reviewed. Judging by my field experience from the Sierra Juárez as well as research by other scholars, I would suggest that the claims about the sweeping destructive impact of Protestantism on indigenous culture and traditional practices are often exaggerated. It would be erroneous to argue that Protestantism is incompatible with the traditional culture always and everywhere. 
One could start with revising the putative opposition between the collectivist communal ethos of indigenous communities and Protestants' individualistic worldview. Various classical studies have assumed that individualism is an inherent characteristic of most Protestant doctrines. It was one of Weber's (1976) main arguments in his account of the Protestant ethic, and the idea was famously also employed by Durkheim (1952: 158-159) in the study of suicide. But the rigid juxtaposition of the Catholic 'communal ideology' and Protestant 'individualism' in the case of Zapotec villages of the Sierra Juárez would be misplaced. Protestants very seldom oppose themselves to the communal mode of living as such but only to its Catholic premises. According to Enrique Ángeles Cruz (personal communication), a Pentecostal lawyer and the director of an organisation called the Christian Defence of Human Rights ${ }^{18}$ in Oaxaca:

For Catholics, the true manifestation of collective communal life is the fiesta where saints are honoured, money is spent and alcohol is consumed. The fact that Protestants and others do not want to take part in this, does not mean that they are necessarily against communal ideology.

Escalante (unpublished) has even argued that individualism does not suit the indigenous community regardless of its religion composition. Even if the majority of the village population are Protestants, the ideology of a 'closed corporate community' based on territoriality tends to be maintained or recreated, he claims. There are, indeed, numerous examples of this, especially in cases when Protestants, expelled from the villages, have formed their own communities elsewhere (e.g. Barabas 1994; Robledo 1997). Hence, even though the individualist elements of Protestantism have been taken for granted since Weber, it would be flawed to regard Protestants as being unconditionally antagonistic towards collectivism. On the contrary, Protestant congregations, in rural Oaxaca especially, have a rather intense ideology of 'communitarianism' of their own, characterised by a strong feeling of solidarity between congregation members, as well as by various collective activities.

The claims that Protestants undermine national symbols and that Protestantism always has a destructive impact on native socio-cultural practices also beg for critical revision. Protestants in the Sierra Juárez, with the possible exception of the Jehovah's Witnesses, rarely oppose themselves to national and patriotic symbols. On the contrary, because communal authorities and Catholics often mistakenly attribute this Jehovah's Witnesses' particularity to all non-Catholic religions, many Protestant churches endeavour to express their nationalist feelings and patriotism as explicitly as possible. In various communities of the Sierra Juárez, Adventists and Pentecostals, for example, have a national flag permanently exposed in their churches to differentiate 


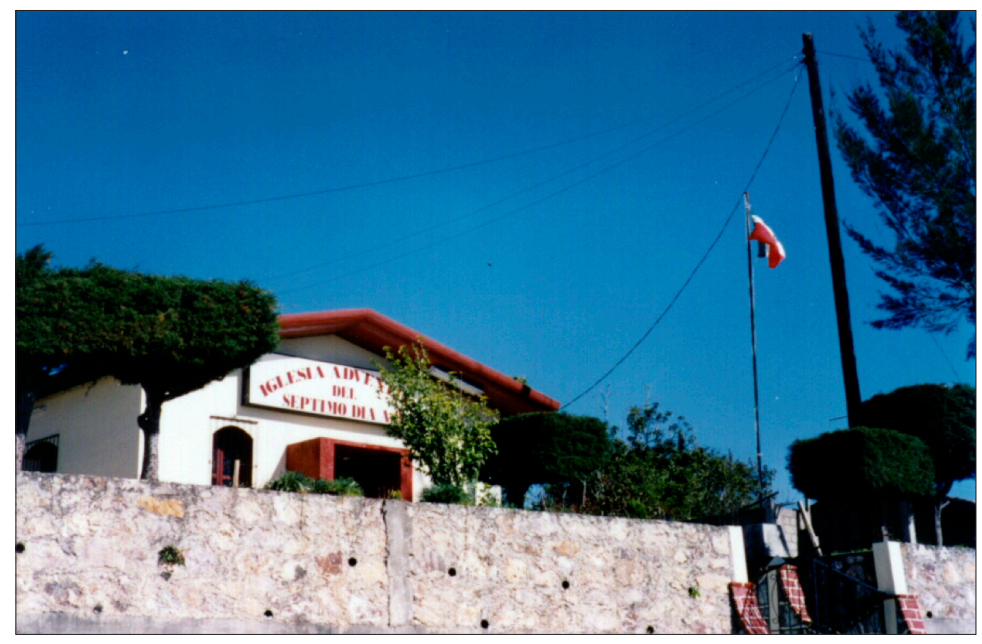

Figure 8. The Adventist church of Capulálpam with a Mexican national flag. Photo by Toomas Gross 2008.

themselves from the Jehovah's Witnesses. Mexican flags are raised on church buildings also during patriotic holidays. As an Adventist informant argued, trying to draw a clear line between his faith and that of the Jehovah's Witnesses:

The Jehovah's Witnesses do not salute the flag, although nowhere in the Word of God is it said that one should not salute the flag. [...] They confuse respect with adoration.

As for the Protestants' relationship with traditional cultural practices, various Protestant churches are capable of adapting to if without assimilating elements of indigenous religion and culture. Many scholars studying Protestantism in Mexico have clearly shown that Protestant presence in the traditional communities does not necessarily 'destroy' local culture (e.g. Sullivan 1998; Cahn 2003). Pentecostalism in particular has been demonstrated to successfully blend with various aspects of indigenous cultures in rural Mexico (e.g. Garma 1998), but the same has also been argued about other Protestant churches. Sánchez (1995: 117), for example, shows that the new religious ideology of Presbyterian converts has not caused drastic changes in the cosmology and everyday practices of Tzeltal villages in Chiapas. Presbyterianism, Sánchez suggests, has instead evolved into a new form of popular religion, from which the Tzeltal-Presbyterian identity is constructed. Gros (1999: 193), in a comparative study of various cases from Latin America, similarly claims that Protestantism does not necessarily erode the ethnic and cultural particularities of indigenous groups, but can actu- 
ally empower them. Protestantism can take indigenous forms, and its impact on local cultures is often not very different from that of folk Catholicism, Gros concludes. Parker (2002) makes a similar argument when suggesting that Protestantism can contribute to the recovery of ethnic identities in Latin America.

In a more recent study from Oaxaca, Gallaher (2007) argues that contemporary Protestant churches have managed to establish a more compatible relationship with indigenous customs, owing to the altered conversion strategies and styles of proselytising by Protestant missionaries. Conversion to Protestantism no longer means rejecting the key aspects of indigenous and rural culture, Gallaher concludes. She pays particular attention to tequios and fiestas, demonstrating that the missionaries' increasingly flexible approach towards these communal practices allows Protestant converts "to be able to continue to function as part of the village rather than stand in opposition to it" (Gallaher 2007: 104).

Not only do most Protestant groups adapt themselves to local cultural contexts, but such adaptation is reciprocal - with time various villages in the Sierra Juárez have 'learned to live' with religious pluralism. An example of this is the community of La Trinidad, the population of which is almost evenly divided between Catholics and Protestants. Many of my informants in other villages often referred to La Trinidad as a model for religious tolerance, pluralism, and collaboration between different religious groups living in the same village. Allegedly, communal authorities in La Trinidad had contributed to the construction and renovation of all church buildings in the village and affiliates of all religious groups had served high-ranking cargos. This does not mean that religious fragmentation has not affected La Trinidad, but its social impact was considered to be mainly positive. Protestantism was claimed to have led, for example, to the decline of alcoholism and corruption.

Although critics accuse Protestantism of undermining the usos y costumbres, much broader and more general processes are often behind the transformation of contemporary indigenous communities. The spread of Protestant churches and changes in the local socio-cultural practices discussed above might be interpreted as being the parallel results of various modernising and globalising forces, such as migration, monetarised economy, neoliberalism, and 'Westernisation', to name a few. These forces have been shaping the Mexican countryside significantly for the past few decades. Tequios in the indigenous villages have traditionally been based on solidarity and collective participation of all villagers, but due to the increasing role of money in local economy, socio-economic stratification and unemployment in rural areas, villagers' relationships with each other are nowadays more monetarised and less based on solidarity. This leads, in the worst cases, to the disappearance of tequio as a collective practice, 
or, like in most communities, to the situation where richer villagers prefer not to 'waste their time' and opt to pay the poor to participate in tequios for them.

Various changes in the system of cargos are likewise a result of the changing socio-economic conditions and the integration of rural communities into national and global economy. In the situation where villages and households are losing self-sufficiency, cargos are increasingly often regarded as a burden, rather than a means of gaining prestige and recognition or expressing one's solidarity with the community. Complaints that non-remunerated cargos are burdensome are equally common among Protestants and Catholics. The municipal presidents (29 altogether) of the villages of the Sierra Juárez, who contested to one my questionnaires, spent nearly ten hours a day on average to fulfil the tasks of their generally three-year cargo, for which none of them received any payment. Only three contestants claimed that working as a Municipal President did not have an adverse effect on their household's welfare and income. Nearly half of them relied on relatives' support, held multiple jobs, or used personal savings and loans to maintain themselves and their families. Although lower-ranking cargos are less time-consuming and hence economically less demanding, evading cargos has become a common reason for out-migration from the villages, as I was often told.

The cases when Protestants refuse to participate in tequios or serve cargos for religious reasons are actually rare. On the contrary, Protestants often regard performing such tasks as a religious obligation, claiming that "the Bible obliges [one] to obey the authorities". Negative reactions to the cargo system and tequios, as argued above, are very specific and determined by the particularity of religious convictions or the nature of the responsibility. Even the transformative impact of Protestantism on fiestas and other religious events, which are central to the cultural and collective identities of indigenous villages, is not as straightforward as generally expected. Olga Montes, an Oaxacan anthropologist and of Zapotec origin herself, has argued that owing to the changes in religious practices and the spread of new modes of faith, indigenous collective identities are reformulated but not destroyed. In my personal communication with her, Montes brought an example of the village of Yatzachi. Although many people in Yatzachi have converted to Pentecostalism in recent years, various religious events like celebrating Christmas have retained their local features. "The Pentecostals feel themselves as much Zapotec as Catholics do," Montes emphasised.

Moreover - like in the case of tequios and the system of cargos - the transformation of fiestas nowadays might be triggered by more general changes in the socio-economic conditions in rural areas. In a thought-provoking analysis, Montes (1995: 27) has suggested that the decline of the fiestas in recent decades can be explained by the changes in agricultural practices, especially by the 
drop in cultivating traditional crops like corn. Most fiestas honouring village saints in Oaxaca take place in summer or in autumn, traditionally the periods of sowing and harvesting corn. Since the middle of the twentieth century, cash crops like coffee and bananas have increasingly replaced the cultivation of traditional crops. Importantly, the cultivation period of these new crops does not coincide with the dates of most fiestas. Villagers have consequently fewer financial resources at hand during the time of the fiesta, which has an adverse impact on the organisation of the event. Moreover, the new crops are generally less dependent on weather conditions and hence do not require the patron saint's blessing, Montes (ibid.) also claims. Apart from the changes in agricultural practices, massive out-migration from the rural areas in search for work and increasing inequality within the villages also contribute to the decline of traditional fiestas.

And finally, even though the Protestants' new faith and worldview often $d o$ encourage a break with certain traditional practices, it has to be emphasised that the rejection of costumbre in contemporary indigenous villages is not an exclusively Protestant feature. Many of my Catholic informants similarly criticised customary norms and traditions, considering various aspects of the usos $y$ costumbres as "obsolete, conservative, and authoritarian." Although it was acknowledged that customs serve to unite the villages into corporate wholes based on a strong sense of solidarity and an ideology of collaboration, the usos $y$ costumbres were also perceived as a normative system that forces people to participate in costly fiestas, hold burdensome cargos, and work for no compensation.

\section{CONCLUSION}

The aim of this article has been to discuss, using the ethnographic example of the indigenous Zapotec communities of the Sierra Juárez in Northern Oaxaca, the complex relationship between Protestantism, traditional culture, and collective communal identity. I have mainly been concerned with the perceptions of the impact of Protestant growth in general on various customs (costumbres) in the indigenous villages, rather than with how conversion to Protestantism transforms the lives of individual converts. This is not to claim that the aggregate impact of many individual transformations has no potential to modify entire communities or societies. On the contrary, it has been convincingly demonstrated that sufficiently many individual conversions may, for example, alter gender relationships in a society (e.g. Brusco 1995; Loreto \& Das Dores 1998) or encourage entrepreneurial mentality (e.g. Annis 1987; Garma 1987). 
As I have demonstrated, Protestant growth in the rural areas and indigenous communities of Oaxaca is often regarded as a cause of profound and significant socio-cultural changes. In the Zapotec villages of the Sierra Juárez, the local population's perception of the impact of Protestant growth on customs, cultural practices, and communal identity has often been negative. Protestant converts are accused of switching to a more individualistic worldview, which is at odds with the collective ethos of an indigenous community. Protestants are claimed to reject various local customs and Protestants' presence is regarded, by most severe critics, as a threat to the cultural integrity and autonomy of the villages.

Although such claims are justified in some cases, it would be erroneous to extrapolate them to all Protestant churches and to all circumstances. I have used the general category 'Protestant' throughout this article as a cover term comprising all non-Catholic biblical churches, because the Catholic majority seldom differentiates between various denominations. From the analytical perspective, however, Protestantism - when it comes to its relationship with local customs and culture - is a multifaceted phenomenon. The impact of 'Protestantisation' on customs and culture is situation- and denomination-specific, and in this context the analytical value of the umbrella category 'Protestant' could even be called into question.

As I have endeavoured to show, critically revising the conventional arguments about the adverse impact of Protestant presence in the villages of the Sierra Juárez, the devastating impact of Protestant churches on local traditions and identities should not be exaggerated. This does not mean that Protestant faith in these traditionally Catholic villages should be regarded as an "old wine in new wineskins", to use Sundkler's (1961: 240) metaphor. Nor should one minimise or deny the transformative effects of conversion, as some anthropologists have done in other ethnographic contexts (e.g. Comaroff \& Comaroff 1991: 248-252). It is evident that Protestant growth changes contemporary communities in the Sierra Juárez. Above all, the religious fragmentation of the traditional villages leads to a certain liberalisation of the 'monolithic mode of communal thinking' rooted in Catholicism. The plurality of religious affiliations and worldviews forces communities to 'think' and 'act' differently in order to come to terms with such novel heterogeneity. But in order to assess the actual impact of Protestantism on more tangible social and cultural phenomena than a 'worldview', the potential role of broader forces behind the changes in contemporary villages should also be considered. Customs and traditional practices 
might change not only due to the fragmentation of the religious field, but also owing to various more general globalising and modernising trends. Moreover, the rise of Protestantism and the socio-cultural changes it is claimed to trigger might, after careful scrutiny, turn out to be co-variants caused by the same underlying processes.

\section{NOTES}

1 This research was supported by the European Union through the European Regional Development Fund (Centre of Excellence CECT), and the Estonian Science Foundation (grant No 8335).

2 I first arrived in Oaxaca in the summer of 1998 as a visiting researcher at the Centre for the Advanced Study and Research in Social Anthropology (Centro de Investigaciones y Estudios Superiores en Antropología Social or CIESAS). Altogether 18 months of continuous fieldwork in the Zapotec villages of the Sierra Juárez produced ethnographic data from 39 communities. I have returned to the Sierra Juárez for shorter periods of fieldwork on multiple occasions, most recently in June 2012.

${ }^{3}$ For the sake of consistency, I am using the term 'Protestant' instead of 'evangelical' throughout this article. In common discourse in Mexico, the categories 'Protestant' (Protestante) and 'evangelical' (evangélico) are often used interchangeably. And, to further simplify the otherwise complex religious terminology, I will use the label 'Protestant' here as a cover-term comprising all non-Catholic Biblical churches, thus including also Jehovah's Witnesses, Mormons, and the Seventh Day Adventists.

4 This does not mean that the Catholic Church in Mexico has always enjoyed state support. After the proclamation of the 1857 constitution and Benito Juárez's Reform Laws of the same decade, and especially during and immediately after the Mexican Revolution, the position of the Catholic Church in the Mexican society was seriously undermined by the state (see, for example, Aguirre 1992; De la Torre 1995).

5 The alleged link between Latin American Protestantism and the US influence has been extensively discussed (e.g. Lalive d'Epinay 1968; Bastian 1994). 'The US conspiracy' argument has been particularly prominent in the studies of the activities of the Summer Institute of Linguistics in Latin America and elsewhere (e.g. Hvalkof \& Aaby 1981; Stoll 1982; De la Torre 1995).

6 In 1900, the percentage of Protestants in Mexico was 0.4 percent and this figure increased at an average rate of two tenths of a percent per decade, reaching 1.8 percent by 1970 . Since then, the growth of Protestant population has been considerably faster. According to the latest general census of 2010, 9.7 percent of the Mexican population professes a non-Catholic Biblical religion. A concise overview of the expansion of Protestantism in Mexico can be found in Dow (2005).

7 For example, 12.9 percent of the indigenous population in Mexico identified themselves as non-Catholic believers in 2000; the equivalent figure for the whole country was 7.6 (Garma \& Hernández 2007: 211). 
8 The figure is based on the data from Mexican general censuses. It must be noted here that the religious categories used in the censuses have changed over time, thus rendering the longitudinal comparison difficult. Until 1990, the censuses distinguished between five religious categories: 'Catholic,' 'Protestant/evangelical,' 'Judaic,' 'other' and 'non-religious' (earlier 'atheist'). Non-evangelical biblical religions (the Seventh Day Adventists, Jehovah's Witnesses, Mormons) were included under the category 'other,' together with various other religious groups. Since the census of 2000 , however, non-evangelical biblical religions are listed as a separate category ('biblical other than evangelical').

9 Until the 1970s, the percentage of Protestants in Oaxaca was lower than the national average but grew rapidly from 1.5 to 7.3 percent in 1970-90. Within these twenty years, the total population of Oaxaca increased by 50 percent, the number of Catholics rose 15 percent, whereas that of Protestants grew an astonishing 531 percent (Marroquín 1995a: 10). By 2010, the percentage of evangelical Protestants in Oaxaca had risen to 10.6 percent and that of all people belonging to a non-Catholic Biblical religion to 13.2 percent.

10 The Zapotecs are among the biggest indigenous groups of Mexico. Most Zapotecs live in the State of Oaxaca, although Zapotec-speaking communities can also be found in the neighbouring states. Zapotec languages and dialects are multiple, but the Zapotec peoples of Oaxaca are generally divided into four groups. This article is concerned with the communities of serranos, as the Zapotec peoples living in the mountainous northern part of Oaxaca are often referred to.

11 The term lacks a good equivalent in English. Its direct translation 'habits and customs' would conceal the multiple meanings that the phrase has, being used simultaneously as a cultural, sociological, and legal concept. See, for example, Stavenhagen (1992), Gómez (1993, 1997), and Sierra (1993) for theoretical analyses of various aspects of customary law in the Mexican context.

${ }^{12}$ In 1992, for example, an amendment was made to the fourth article of the federal constitution, which stipulates the multicultural composition of the Mexican nation and secures the plurality of judicial practices and customs in the country (Valdivia 1994: 17).

${ }^{13}$ Protestants' urge to break with the past has been eloquently described by anthropologists in multiple ethnographic contexts (e.g. Meyer 1998; Robbins 2003, 2007; Engelke 2004, 2010).

${ }^{14}$ Llaveros are generally responsible for different tasks in the local Catholic church.

${ }^{15}$ Regidor is a cargo roughly in the centre of the hierarchical 'ladder' of cargos. Villages in the Sierra Juárez usually have many regidors who are responsible for a certain sector of communal affairs, such as education or construction of roads.

${ }^{16}$ En la Sierra, graves conflictos religiosos. Noticias, 28 May 1989.

${ }^{17}$ Afirma edil de San Juan Yaeé: el pueblo y no yo, es el que castigó a los evangélicos. Noticias, 3 July 1996. In June 1998, the village authorities finally allowed the expelled families to return. 
${ }^{18}$ DECRISDH (La Defensa Cristiana de los Derechos Humanos) was founded in 1991 in response to mounting religious intolerance against Protestants in Oaxaca.

\section{REFERENCES}

Aguirre Beltrán, Gonzalo 1991 [1953]. Formas de gobierno indígena. México, D.F.: Fondo de Cultura Económica.

Aguirre Beltrán, Gonzalo 1992. Zongolica. Encuentro de dioses y santos patronos. México, D.F.: Fondo de Cultura Económica.

Alatorre Frenk, Gerardo 1998. La empresa social forestal y sus asesores: avances y dificultades en la construcción de la democracia, la eficiencia y la sustentabilidad. (Doctoral thesis in anthropology). México, D.F.: UNAM.

Annis, Sheldon 1987. God and Production in a Guatemalan Town. Austin: University of Texas Press.

Barabas, Alicia M. 1994. Movimientos sociorreligiosos e identidad. Runa 21, pp. 35-52.

Barabas, Alicia M. 2006. Los retos actuales para las tradiciones indígenas: procesos de transformación y reelaboración en Oaxaca. Alteridades 32 (2), pp.113-131.

Bastian, Jean-Pierre. 1994. Protestantismos y modernidad latinoamericana: historia de unas minorías religiosas activas en América Latina. México, D.F.: Fondo de Cultura Económica.

Blancarte, Roberto 1992. Historia de la Iglesia Católica en México 1929-1982. México, Colegio Mexiquense: Fondo de Cultura Económica.

Brusco, Elizabeth E. 1995. The Reformation of Machismo: Evangelical Conversion and Gender in Colombia. Austin: University of Texas Press.

Cahn, Peter 2003. All Religions Are Good in Tzintzuntzan. Austin: University of Texas Press.

Crivelli, Camillo 1929. Sectas y sociedades protestantes en la América Latina. El Paso: Revista Católica.

Comaroff, Jean \& Comaroff, John 1991. Of Revelation and Revolution: Christianity, Colonialism, and Consciousness in Southern Africa. Volume One. Chicago: University of Chicago Press.

De la Fuente, Julio 1977. Yalálag: una villa zapoteca serrana. México, D.F.: INI.

De la Torre, Angela Renée 1995. Los hijos de la luz: Discurso, identidad y poder en La Luz del Mundo. Guadalajara: Universidad de Guadalajara.

Dow, James W. 2005. The Expansion of Protestantism in Mexico: An Anthropological View. Anthropological Quarterly 78 (4), pp. 827-850, doi:10.1353/anq.2005.0054.

Durand Alcántara, Carlos Humberto 1998. Derecho nacional, derechos indios y derecho consuetudinario indígena: los triquis de Oaxaca, un estudio de caso. Chapingo: Universidad Autónoma Chapingo; México, D.F.: Universidad Autónoma Metropolitana.

Durkheim, Émile 1952 [1897]. Suicide: A Study in Sociology. London: Routledge and Kegan Paul.

Engelke, Matthew 2004. Discontinuity and the Discourse of Conversion. Journal of Religion in Africa 34 (1/2), pp. 82-109, doi:10.1163/157006604323056732. 
Engelke, Matthew 2010. Past Pentecostalism: Notes on Rupture, Realignment, and Everyday Life in Pentecostal and African Independent Churches. Africa 80 (2), pp. 177-199, doi:10.3366/afr.2010.0201.

Escalante Betancourt, Yuri. Conflicto religioso y prácticas jurídicas en comunidades indígenas de México. Unpublished manuscript.

Esquivel Obregón, Toribio 1946. La propaganda Protestante en México a la luz del derecho internacional y del más alto interés de la nación. México, D.F.: Publicaciones de la Academia Mexicana de Jurisprudencia y Legislación.

Gallaher, Carolyn 2007. The Role of Protestant Missionaries in Mexico's Indigenous Awakening. Bulletin of Latin American Research 26 (1), pp. 88-111, doi:10.1111/ j.1470-9856.2007.00211.x.

Gamio, Manuel. 1982 [1916]. Forjando patria: pro-nacionalismo. México, D.F.: Editorial Porrúa.

Garma Navarro, Carlos 1987. Protestantismo en una comunidad totonaca de Puebla, México. México, D.F.: INI.

Garma Navarro, Carlos 1998. The socialization of the gifts of tongues and healing in Mexican Pentecostalism. Journal of Contemporary Religion 13 (3), pp. 353-361.

Garma Navarro, Carlos \& Hernández Hernández, Alberto 2007. Los rostros étnicos de las adscripciones religiosas. In: Renée de la Torre \& Christina Gutiérrez Zúñiga (eds.) Atlas de la diversidad religiosa en México. México, D.F.: CIESAS, pp. 203-226.

Garrard-Burnett, Virginia. 1993. Conclusion: Is This Latin America's Reformation? In: Virginia Garrard-Burnett \& David Stoll (eds.) Rethinking Protestantism in Latin America. Philadelphia: Temple University Press, pp. 199-210.

Gómez, Magdalena 1993. Hacia una definición del espacio de lo consuetudinario en el medio indígena y de sus posibilidades de ejercicio en el marco de la nueva legalidad. Nueva Antropología 44, pp. 9-15.

Gómez, Magdalena (ed.) 1997. Derecho indígena. México: INI.

González Galván, Jorge Alberto 1994. El derecho consuetudinario indígena en México. In: José Emilio R. Ordóñez Cifuentes (ed.) Cosmovisión y prácticas jurídicas de los pueblos indios. México, D.F.: UNAM.

Gros, Christian 1999. Evangelical Protestantism and Indigenous Populations. Bulletin of Latin American Research 18 (2), pp. 175-197, doi:10.1016/S0261-3050(98)00092-8.

Gross, Toomas 2003. Protestantism and Modernity: The Implications of Religious Change in Rural Oaxaca. Sociology of Religion: A Quarterly Review 64 (4), pp. 479-498, doi:10.2307/3712337.

Gutiérrez Zúñiga, Cristina \& Janssen, Eric \& De la Torre, Renée \& Aceves, Ana Rosa 2007. Los rostros económicos de las adscripciones religiosas. In: Renée de la Torre \& Christina Gutiérrez Zúñiga (eds.) Atlas de la diversidad religiosa en México. México, D.F.: CIESAS, pp. 187-202.

Hernández Hernández, Alberto 2007. El cambio religioso en México: crecimiento y auge del pentecostalismo. In: Carolina Rivera Farfán \& Elizabeth Juárez Cerdi (eds.) Más allá del espíritu: Actores, acciones y prácticas en las iglesias pentecostales. México, D.F.: CIESAS, pp. 53-90.

Hirabayashi, Lane R. 1993. Cultural Capital: Mountain Zapotec Migrant Associations in Mexico City. Tucson: The University of Arizona Press. 
Hvalkof, Søren \& Aaby, Peter (eds.) 1981. Is God American? An Anthropological Perspective on the Missionary Work of the Summer Institute of Liguistics. Copenhagen \& London: IWGIA/SI.

Kearney, Michael 1971. Los vientos de Ixtepeji. México, D.F.: Instituto Indigenista Interamericano.

Lalive d'Epinay, Christian 1968. El Refugio de las Masas: estudio sociológico del Protestantismo Chileno. Santiago de Chile: Editorial de Pacífico.

Loreto Mariz, Cecília \& das Dores Campos Machado, María 1997. Pentecostalism and Women in Brazil. In: Edward. L. Cleary \& Hannah W. Stewart-Gambino (eds.) Power, Politics, and Pentecostals in Latin America. Boulder: Westview Press, pp. 41-54.

Marroquín Zaleta, Enrique 1995a. Introducción. In: Enrique Marroquín Zaleta (ed.) ¿Persecución religiosa en Oaxaca? Oaxaca: Instituto Oaxaqueño de las Culturas, pp. 9-21.

Marroquín Zaleta, Enrique 1995b. Los disidentes religiosos: ¿intolerancia o resistencia cultural? In: Enrique Marroquín Zaleta (ed.) ¿Persecución religiosa en Oaxaca? Oaxaca: Instituto Oaxaqueño de las Culturas, pp. 71-121.

Martin, David. 1990. Tongues of Fire: The Explosion of Protestantism in Latin America. Oxford: Blackwell.

Meyer, Birgit 1998. 'Make a Complete Break with the Past'. Memory and Post-Colonial Modernity in Ghanaian Pentecostalist Discourse. Journal of Religion in Africa 28 (3), pp. 316-349.

Mondragón González, Carlos 2005. Leudar la masa: el pensamiento social de los protestantes en América Latina, 1920-1950. Buenos Aires: Kairos Ediciones.

Mondragón Lievana, Carlos 1994. Protestantismo, panamericanismo e identidad nacional, 1920-1950. In: Roberto Blancarte (ed.) Cultura e identidad nacional. México, D.F.: Fondo de Cultura Económica, pp. 305-342.

Montes García, Olga 1995. Los conflictos religiosos en Oaxaca: una aproximación a su estudio. In: Enrique Marroquín Zaleta (ed.) ¿Persecución religiosa en Oaxaca? Oaxaca: Instituto Oaxaqueño de las Culturas, pp. 23-70.

Montes García, Olga 1997. Movimientos religiosos en Oaxaca: sus características. Religión y Sociedad 1 (4), pp. 43-65.

Nader, Laura 1990. Harmony Ideology: Justice and Control in a Zapotec Mountain Village. Stanford: Stanford University Press.

Parker Gumucio, Cristián 2002. Religion and the Awakening of Indigenous People in Latin America. Social Compass 49 (1), pp. 67-81.

Patterson, Eric 2005. Latin America's Neo-Reformation: Religion's Influence on Contemporary Politics. New York: Routledge.

Robbins, Joel 2003. On the Paradoxes of Global Pentecostalism and the Perils of Continuity Thinking. Religion 33 (3), pp. 221-31, doi:10.1016/S0048-721X(03)00055-1.

Robbins, Joel 2007. Continuity Thinking and the Problem of Christian Culture: Belief, Time, and the Anthropology of Christianity. Current Anthropology 48 (1), pp. 5-38, doi:10.1086/508690.

Robledo Hernández, Gabriela 1997. Disidencia y religión: Los expulsados de San Juan Chamula. Tuxtla Gutiérrez \& Chiapas: Universidad Autónoma de Chiapas. 
Sánchez Franco, Irene 1995. Los Presbiterianos Tzeltales de Yajalon, Chiapas (BA Thesis). San Cristobal de las Casas: Universidad Autónoma de Chiapas.

Sault, Nicole L. 2001. Godparenthood Ties Among Zapotec Women and the Effects of Protestant Conversion. In: James W. Dow \& Alan R. Sandstrom (eds.) Holy Saints and Fiery Preachers: The Anthropology of Protestantism in Mexico and Central America. Westport: Praeger, pp. 117-146.

Sierra, María Teresa 1993. Usos y desusos del derecho consuetudinario indígena. Nueva Antropología 44, pp. 17-26.

Stavenhagen, Rodolfo 1992. Los derechos de los indígenas: algunos problemas conceptuales. Nueva Antropología 43, pp. 83-99.

Stoll, David. 1982. Fishers of men or founders of empire? The Wycliffe Bible Translators in Latin America. London: Zed Press.

Stoll, David. 1990. Is Latin America Turning Protestant? The Politics of Evangelical Growth. Berkeley: University of California Press.

Sullivan, Kathleen 1998. Religious Change and the Recreation of Community in an Urban Setting among the Tzotzil Maya of Highland Chiapas, Mexico (Ph.D. Dissertation). New York: City University of New York.

Sundkler, Bengt G. M. 1961 [1948]. Bantu Prophets in South Africa. London: Oxford University Press.

Valdivia Dounce, Teresa (ed.) 1994. Usos y costumbres de la población indígena de México: Fuentes para el estudio de la normatividad (Antología). México, D.F.: INI.

Weber, Max 1976 [1904-5]. The Protestant Ethic and the Spirit of Capitalism. London: George Allen \& Unwin.

Willems, Emilio 1964. Protestantism and Culture Change in Brazil and Chile. In: William V. D'Antonio \& Frederick B. Pike (eds.) Religion, Revolution, and Reform: New Forces for Change in Latin America. London: Burns \& Oates, pp. 93-108.

Willems, Emilio 1967. Followers of the New Faith: Culture Change and the Rise of Protestantism in Brazil and Chile. Nashville: Vanderbildt University Press.

Wolf, Eric 1958. The Virgin of Guadalupe: A Mexican National Symbol. Journal of American Folklore 71 (279), pp. 34-39, doi:10.2307/537957. 